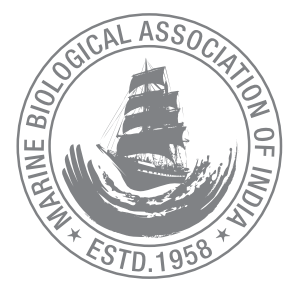

\title{
Fishery, biology and stock assessment of spotted seer, Scomberomorus guttatus (Bloch \& Schneider) off Andhra Pradesh
}

\author{
V. U. Mahesh, S. Ghosh ${ }^{*}$ K. Sreeramulu', M. V. Hanumantha Rao and M. Satish Kumar \\ Visakhapatnam Regional Centre of ICAR-CMFRI, Pandurangapuram, Visakhapatnam-530 003, Andhra Pradesh, India \\ 'Department of Zoology, Andhra University, Visakhapatnam-530 003, Andhra Pradesh, India \\ *Correspondence e-mail: subhadeep_1977@yahoo.com
}

\begin{abstract}
The fishery, biology and stock of the spotted seerfish, Scomberomorus guttatus (Bloch \& Schneider) along Andhra Pradesh was studied during 2012-2014. The annual average landing of spotted seer during the period along Andhra coast was 2,614 t. Major contributors were trawlnets-1,104 t (42.2\%) and gillnets-950 t (36.3\%). Catches were higher during August-December. Length-weight relationship varied significantly between males, females and indeterminates. Growth was isometric in males and allometric in females and indeterminates. Overall sex ratio was 1:1.87. Length at first maturity was $38.9 \mathrm{~cm}$. Peak spawning was observed during November-April. Higher Gonadosomatic index coincided with periods of peak spawning. Mature ovaries contained both maturing $(0.41 \mathrm{~mm}-0.70 \mathrm{~mm})$ and matured $(0.71 \mathrm{~mm}-0.90 \mathrm{~mm})$ ova. von Bertalanffy growth equation was $L_{t}=71.98[1-e-0.23(t+0.0722)$. Natural mortality, fishing mortality and total mortality were $0.54,0.49$ and 1.03 . Exploitation ratio was 0.48 . Annual total stocks, biomass and Maximum Sustainable Yield were 8,546 $\mathrm{t}_{\text {, }}$ $5,335 \mathrm{t}$ and 2,747 t. A minor increase in yield and yield/recruit is possible by increasing the present level of fishing by $20 \%$.
\end{abstract}

Keywords: Fishery, biology, stock structure, Scomberomorus guttatus, Andhra Pradesh

\section{Introduction}

Andhra Pradesh is one of the leading seerfish producing states in India, with the catch made up by spotted seer, Scomberomorus guttatus (Bloch \& Schneider) and the king seer $S$. commerson (Lacepede). Seerfishes formed on an average 3.5\% of the national marine landings during 2000-2014. Recent landings in India fluctuated from 56,170 $t$ in 2012 to 49,209 $t$ in 2014, with an all-time peak of 62,171 t in 2007. Landings in Andhra Pradesh have increased from 5,437 t in 2000 to 7,729 $\mathrm{t}$ in 2014, with highest catch of $11,466 \mathrm{t}$ recorded in 2007. The contribution of $S$. guttatus to the total seerfish catch in recent years has increased at the expense of $S$. commerson. It now contributes on average $37.8 \%$ of the total seerfish caught (Maheswarudu et al., 2013).

S. guttatus is an epipelagic, neritic species known to undertake longshore migrations (Randall, 1995). It is exploited by a variety of gears viz., drift gill nets, hook and lines, trolling, trawl nets and seines (Ghosh et al., 2009). S. guttatus is heavily concentrated and highly localized with bulk of the fishery from within a narrow belt of $45 \mathrm{~km}$ at depth range of 20-70 m. Hence, it could well be possible that the resource is currently overexploited. It islocally known as 'Vanjaram' owing to its high unit value 
and economic returns, and hence is one of the commercially important marine pelagic finfish resources of the state and the country. The catches are mostly consumed fresh or frozen.

Historical information is available on the fishery and stock dynamics of spotted seer from waters all along the Indian coast (Devaraj, 1977, 1981, 1987; Kasim et al., 2002; Muthiah et al., 2002; Kasim and Abdussamad, 2003; Muthiah et al., 2005; Ghosh et al., 2009). However specific studies from Andhra Pradesh are lacking. No information is available on the fishery, biology and stock status of the spotted seer from the east coast for the last decade or more. Hence, the present study focuses on elucidating the fishery, reproductive biology and stock assessment of $S$. guttatus from the waters off Andhra Pradesh.

\section{Material and methods}

Catch data of $S$. guttatus and effort expended were collected weekly from all gears at Palasa, Mukkam, Visakhapatnam, Pudimadaka, Kakinada, Machilipatnam and Odarevu, Andhra Pradesh, for three years from January 2012 to December 2014. Monthly and annual estimates of catches were made following the procedure adopted by the Fishery Resource Assessment Division of Central Marine Fisheries Research Institute, India (Srinath et al., 2005).

A total of 4,668 specimens of $S$. guttatus ranging in size from 20.0 to $69.0 \mathrm{~cm}$ were collected randomly and measured for fork length $(\mathrm{cm})$ and body weight ( $\mathrm{g}$ to $0.01 \mathrm{~g}$ precision). Length-weight relationship was calculated as $\mathrm{W}=\mathrm{aL}^{\mathrm{b}}$ (Le Cren, 1951), separately for both sexes and indeterminates. Significant differences between males, females and indeterminates in the slopes of the regression lines were ascertained by ANACOVA (Snedecor and Cochran, 1967). Sex ratio for each month during the period was estimated from 4,388 specimens, with chi-square test done for testing the distribution of homogeneity of male and female. Size at first maturity $\left(L_{50}\right)$ was estimated from 2,827 female specimens using the nonlinear least square regression method, logistically by fitting the fraction of mature fish (stage III and above) against length interval (King, 1995). Spawning season was ascertained by estimating the proportion of gravid and ripe females ( $V$ and $\mathrm{VI}$ ) over months. Gonadosomatic index (GSI) for females was calculated as GSI = (weight of gonad $\times 100) /$ weight of fish. The number of ova in all subsamples, obtained from the anterior, middle and the posterior regions of mature and ripe ovary $(\mathrm{V}$ and $\mathrm{VI})$, was raised to the total ovary weight for determining fecundity. Ova diameter distribution in each ovary subsample was studied using calibrated ocular micrometer under a microscope.

As stock assessment procedures works with age composition, in tropical waters, von Bertalanffy growth model is used, which converts length frequency data into age composition (Sparre and Venema, 1998). Month-wise length composition data of three years were pooled and grouped with $1 \mathrm{~cm}$ class interval and analyzed for estimation of von Bertalanffy growth parameters, Lo and K, using the ELEFAN I module of FiSAT software version 1.2.0 (Gayanilo et al., 1996). Growth performance index $(\phi)$ was computed employing Pauly and Munro (1984). Size at first capture $\left(L_{c}\right)$ was determined as by Pauly (1984). From the empirical equation, $\log \left(-\mathrm{t}_{0}\right)=-0.392$ 0.275 Log Lœ-1.038K (Pauly, 1979), age at zero length $\left(t_{0}\right)$ was calculated. von Bertalanffy growth equation, $L t=L_{\infty}$ (1-exp-k $\left.{ }^{k}(t-t)\right)$, was used for determining age and growth. Length at recruitment $(\mathrm{Lr} r$ was taken as the midpoint of the smallest length group in the catch. Longevity or $t_{\max }$ was determined as $3 / \mathrm{K}+\mathrm{t}_{0}$ (Pauly, 1983a). Natural mortality (M) was estimated using the formulae of Pauly (1980) taking mean sea surface temperature as $28^{\circ} \mathrm{C}$ (International Comprehensive Ocean Atmospheric Data Sets; http://www.esrl.noaa.gov/ psd). Length converted catch curve, using FiSAT software, was used to calculate total mortality (Z) (Pauly, 1983b). Fishing mortality (F) was calculated by substracting $\mathrm{M}$ from Z. Fishing mortalities per length class were obtained from length structured virtual population analysis (VPA) of FiSAT. Exploitation ratio (E) was $F / Z$. The ratios $Y / U$ and $Y / F$ were used to estimate total stock (P) and biomass (B); where $Y$ is the annual average yield in tonnes and $U$ is the exploitation rate. Maximum Sustainable Yield (MSY) was calculated by the equation of Gulland (1979). Beverton and Holt Yield per Recruit model was used to estimate the relative yield per recruit $(\mathrm{Y} / \mathrm{R})$ and biomass per recruit $(\mathrm{B} / \mathrm{R})$ at varying levels of fishing intensity using Excel worksheet.

\section{Results}

\section{Fishery}

During 2012-2014, an annual average of 2,614 $t$ of spotted seer was landed along Andhra Pradesh coast. Catches has increased over the years from 2,356 t in 2012 to $4,142 \mathrm{t}$ in 2014 (Fig. 1). Major contributors were trawlnets and gill nets, contributing on an average annually $1,104 \mathrm{t}(42.2 \%)$ and $950 \mathrm{t}(36.3 \%)$. Contributions were low from hooks and lines (345.5 $t$ and $13.2 \%$ ) and seine nets (214.6 $t$ and $8.2 \%$ ). Average catch rates in trawl nets, gill nets, hooks and lines and seinenets were $0.25 \mathrm{~kg} / \mathrm{h}, 1.30 \mathrm{~kg} / \mathrm{unit}, 0.44 \mathrm{~kg} /$ unit and $1.77 \mathrm{~kg} /$ unit. It formed $1.20 \%, 1.18 \%, 0.52 \%$ and $0.21 \%$ of the total catches in trawlnets, gill nets, hooks and lines and seinenets. In trawl nets (2,310 t) and seine nets $(575 \mathrm{t})$, catches have increased drastically in 2014. On the contrary, in gill nets $(1,112 \mathrm{t})$ and hooks and lines (543 t), landings were highest in 2012. Monthwise, August-December recorded higher catches (Fig. 2) for trawl nets, gill nets and hooks and lines. 


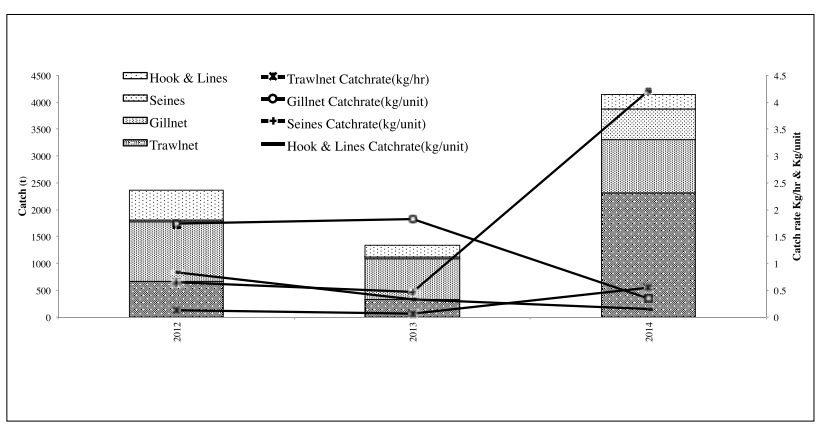

Fig. 1. Annual catch and catch rates of $S$. guttatus

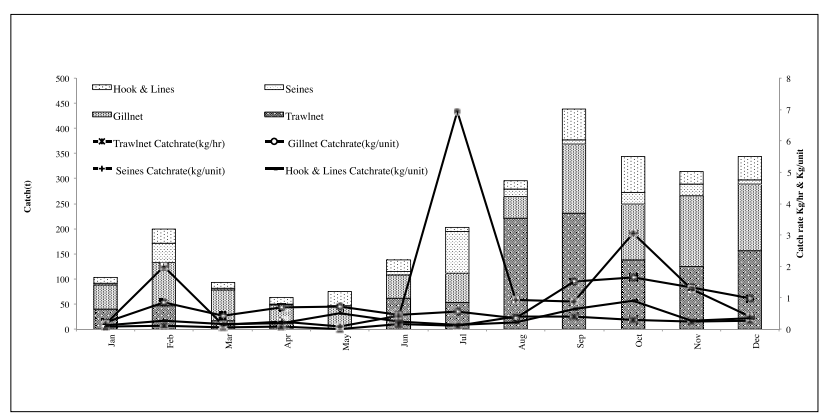

Fig. 2. Monthly catch and catch rates of S. guttatus

\section{Length composition}

Unimodal length frequency was observed with a single peak representing size ranges from $40.5 \mathrm{~cm}$ to $49.5 \mathrm{~cm}$, which are thought to dominate the fishery. More juveniles were encountered in 2012 and 2013, when compared to 2014, especially during June-September. Mean length was more or less similar, varying marginally from $44.29 \pm 2.31 \mathrm{~cm}(2012)$ to $45.05 \pm 2.32 \mathrm{~cm}$ (2013). Seasonally, it fluctuated from $42.6 \pm 0.73$ $\mathrm{cm}$ in August to $46.39 \pm 1.47 \mathrm{~cm}$ in December (Fig. 3).

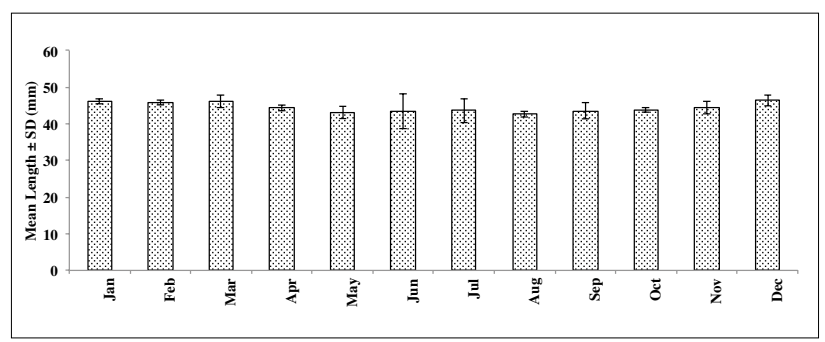

Fig. 3. Mean length of $S$. guttatus in different months

The length-weight relationships estimated separately for sexes and indeterminates were:

Male $: \log W=-2.1716+2.9950 \log L\left(r^{2}=0.91\right)$

Female $: \log W=-1.5031+2.5936 \log L\left(r^{2}=0.90\right)$

Indeterminate $: \log W=0.2128+1.5258 \log L\left(r^{2}=0.89\right)$
The length-weight relationship for males, females and indeterminates were found to be significantly different at 5 $\%$ level. Slopes of the regression relation for females $\left(t_{c a l}=\right.$ $\left.25.21 ; \mathrm{t}_{\text {crit } 0.05}=1.96\right)$ and indeterminates $\left(\mathrm{t}_{\text {cal }}=49.30 ;\right.$ tcrit 0.05 $=1.97$ ) were significantly different from the isometric value of 3 indicating negatively allometric growth; whereas in males, the slope $\left(t_{\text {cal }}=0.21 ;\right.$ tcrit $\left.0.05=1.96\right)$ did not deviate from 3 indicating isometric growth.

\section{Sex Ratio and Size at first maturity}

Significant dominance $(p<0.05)$ was observed by females during August-March. Overall sex ratio was 1:1.87. Males outnumbered females marginally $(p>0.05)$ during May-July. Annual sex ratio varied from 1.80 (2012) to 2.03 (2013). Sexual maturity is reached at a size of $38.9 \mathrm{~cm}$ (Fig. 4). However, gonadal development and sexual maturity commenced from $31.5 \mathrm{~cm}$ onwards.

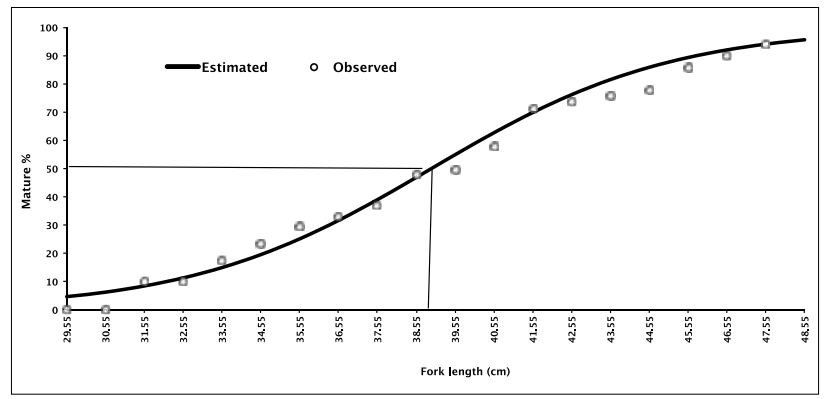

Fig. 4. Length at first maturity for females of S. guttatus

\section{Spawning season and Gonado somatic index (GSI)}

For spotted seer, high proportion of mature females was observed in most months of the year, with mature females available throughout the year. Peak spawning (46.4\%-51.3\% of mature females) were observed between November and April. GSI, similarly, was higher between November-March (1.16-1.27). GSI results are in full conformity to the presence of mature females (Fig. 5). Peak GSI values ranging from 1.26-1.27 was observed during November-December.

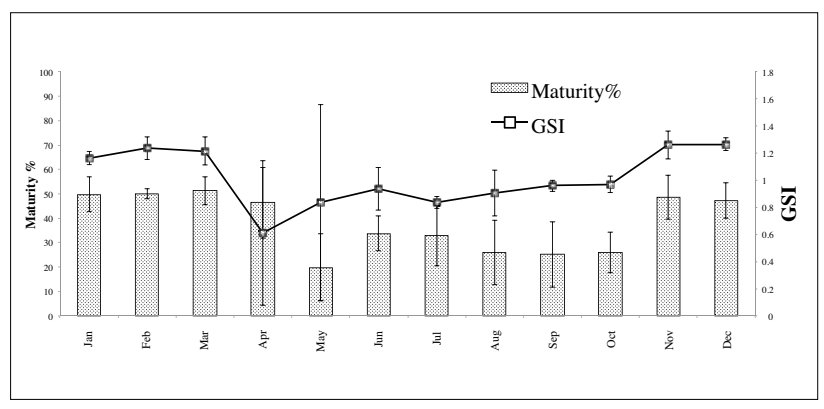

Fig. 5. Maturity and gonadosomatic index (GSI) of females in different months 


\section{Fecundity and ova distribution}

Fecundity increased with the length and weight of the fish. Relation between fecundity and length was $\log F=2.83+$ $1.46 \log L\left(r^{2}=0.79\right)$ and between fecundity and weight was $\log F=4.27+0.35 \log W\left(r^{2}=0.71\right)$. Absolute fecundity ranged from 1,25,440 eggs to 2,46,601 eggs, with a mean of $1,95,388$ eggs. Relative fecundity per $\mathrm{g}$ body weight varied from 131.52 eggs to 310.17 eggs with an average of 253.51 eggs. Mature ovaries contained both maturing and mature ova. Mature ova ranged from 0.71 to $0.90 \mathrm{~mm}$ in diameter whereas the maturing ova ranged from 0.41 to $0.70 \mathrm{~mm}$ (Fig. 6). Yolked ova of different sizes in mature ovaries observed for most months of the year.

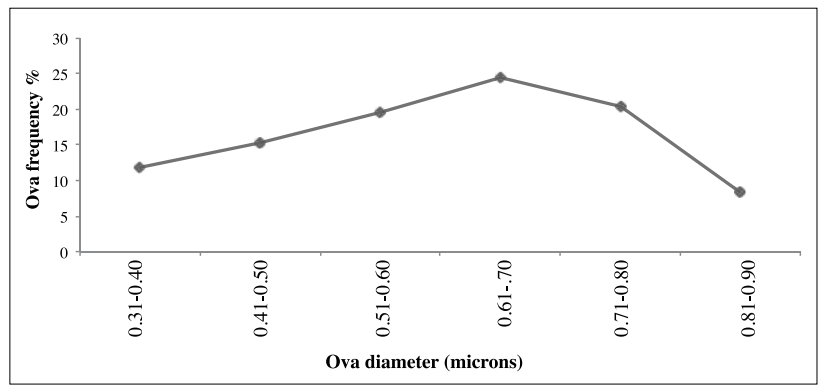

Fig. 6. Ova diameter distribution in females

\section{Growth}

Growth parameters, $L_{\infty}$ and $K$ (annual) estimated using the ELEFAN I programme were $71.98 \mathrm{~cm}$ and 0.23 /year. Growth performance index $(\phi)$ was 3.08 and $t_{0}$ was -0.0722 years. von Bertalanffy growth equation was: $L_{t}=71.98\left[1-\exp ^{-0.23(t+0.0722)}\right]$.

The fish attained size of $15.73 \mathrm{~cm}, 27.29 \mathrm{~cm}, 36.47 \mathrm{~cm}, 43.77$ $\mathrm{cm}$ and $49.56 \mathrm{~cm}$ respectively by the end of $1,2,3,4$ and 5 years. Longevity was close to 13 years. Fishery was dominated by fishes of 4 and 5 year old classes. Length at first capture $\left(L_{C}\right)$ was $20.28 \mathrm{~cm}$, which corresponds to an age $\left(t_{c}\right)$ of 1.37 year.

\section{Recruitment}

The recruitment pattern observed was bimodal with recruitment occurring in all months for $S$. guttatus. One peak in recruitment was during March-April and the other between June-August. Recruitment pulse during March-April produced $26.92 \%$ of the recruits and that during June-August produced $38.92 \%$ of the recruits. Average annual recruit into the fishery was 3,03,02,544 numbers. Smallest length of recruitment was $19.55 \mathrm{~cm}$.

\section{Mortality, exploitation and Virtual Population Analysis}

Mortality rates $M, F$ and $Z$ were $0.54,0.49$ and 1.03 respectively. The exploitation ratio $(\mathrm{E})$ was 0.48 . The main loss in the stock up to $38.5 \mathrm{~cm}$ size was due to natural causes, as indicated by VPA. Fishes became more vulnerable to the gear after this size and mortality due to fishing increased. Fishing mortality was equal to natural mortality at lengths of $55.5 \mathrm{~cm}$ and outnumbered natural mortality at $60.5 \mathrm{~cm}$. Fishing mortality was maximum, 0.548 at size of $60.5 \mathrm{~cm}$.

\section{Stock and Maximum Sustainable Yield (MSY)}

The annual total stock, biomass and MSY were 8,546 t, 5,335 t and 2,747 t, respectively.

\section{Yield / Recruit}

Yield and biomass curves revealed yield and yield/recruit to marginally increase by increasing the present fishing level by $20 \%$ (Fig. 7). Maximum yield and yield per recruit obtained by increasing the present fishing intensity by $20 \%$ is $2,635.5$ $t$ and $86.97 \mathrm{~g}$, whereas at the present level of fishing, it is $2,614.0 \mathrm{t}$ and $86.26 \mathrm{~g}$. At the increased effort, the increase in relative yield is only a marginal $0.82 \%$, which may not be remunerative (Fig. 8).

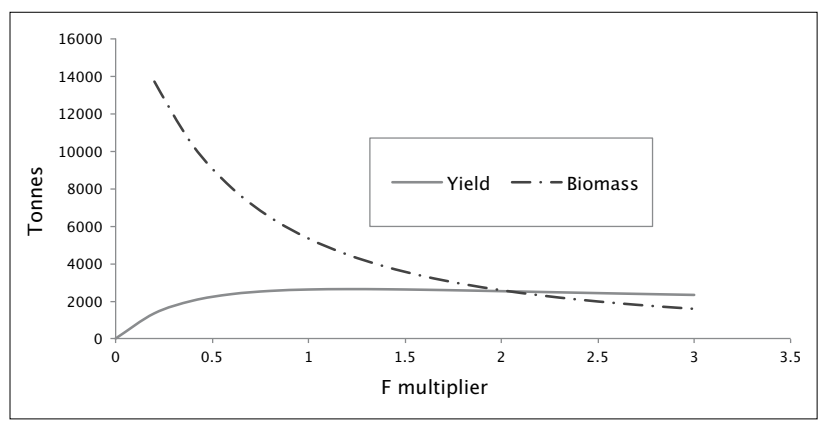

Fig. 7. Yield and biomass of $S$. guttatus for different multiples of fishing intensity

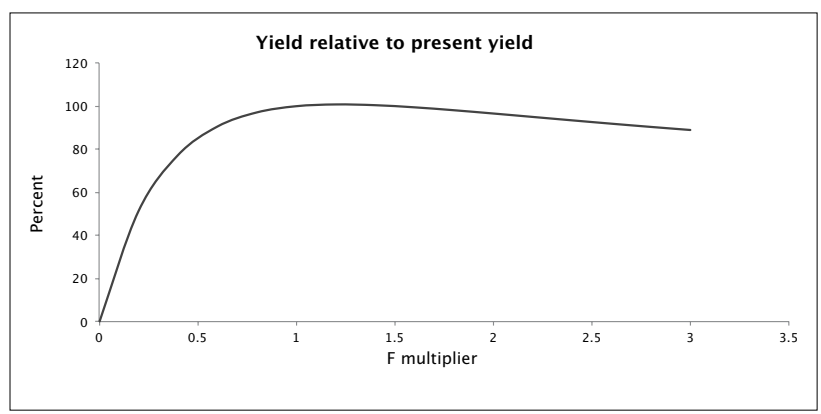

Fig. 8. Relative yield of S. guttatus for different scenarios of fishing intensity

\section{Discussion}

Spotted seer catch has increased over the years. Earlier, highest landing of 4,139 t was reported by Maheswarudu et al. (2013). In the present study, 4,142 t were landed in 2004, which is the highest recorded landing of $S$. guttatus from the waters of Andhra Pradesh till date. A multitude of gears (trawlnets, gill 
nets, hooks and lines and seinenets) exploit the resource in the state. Peak landings in individual gears are commensurate with the increased effort of the gear. Trawlnets with cod end mesh ranging from 20 to $30 \mathrm{~mm}$ exploit $S$. guttatus, as do gill nets (multifilaments and monofilaments) having mesh size ranging from 30 to $150 \mathrm{~mm}$. Smaller meshed gill nets land juveniles, whereas large meshed gill nets land adults. The differences in the fishing grounds and the depth of operation coupled with changes in the distribution of the species account for the variations in catch and catch rates observed among various gears and various months.

Length and weight ranges recorded were similar to that reported earlier from Indian waters (Naik et al., 1998). Mean length was more or less similar, with minimal fluctuations. Silk (small meshed gill) nets are operated between July-September, which land good catches of juveniles of $S$. guttatus (Maheswarudu et al., 2013). Length-weight relationship varied significantly between males, females and indeterminates. Growth was isometric in males and negatively allometric in females and indeterminates. Similar exponent values varying from 2.82 to 2.89 were reported earlier by Devaraj (1981), Naik et al. (1998) and Ghosh et al. (2009). Length weight relationship is influenced by changes in ecosystem and in biological phenomena like maturity stages, feeding behavior and competition for food.

As reported earlier by Bal and Rao (1990) and Naik et al. (1998), there was a dominance of females in the catch. Differential fishing caused by changes in the pattern of migration of sexes to and from the fishing grounds could have attributed to this dominance. Fish attained sexual maturity and spawned at the end of third year. Length at first maturity is similar to that reported earlier (Bal and Rao, 1990).

Devaraj (1987) reported on an extended spawning period from January-August, with a peak in April-May. The same author reported on the occurrence of three batches of ova in mature ovary of different stages of maturity. Kasim and Hamsa (1989) reported peak spawning during July. Contrarily, along Andhra Pradesh, peak spawning occurred between November and April. Also ripe ovaries contained two batches of ova, one maturing and the other mature. Higher values of gonadosomatic index coincided with peak periods of spawning. The size progression of yolked ova during different months is in concurrence to the spawning season. Fecundity estimates are lower than 3,85,000 eggs to $11,00,000$ eggs reported by Bal and Rao (1990).

The asymptotic length observed in the study was $71.98 \mathrm{~cm}$ which is closer to $72.4 \mathrm{~cm}$ reported by Muthiah et al. (2002) and $75.0 \mathrm{~cm}$ reported by Kasim et al. (2002) from the east coast of India. From the west coast, lower values $(61.3 \mathrm{~cm}, 64.3$ $\mathrm{cm}$ and $65 \mathrm{~cm}$ ) were reported (Ghosh et al., 2009; Muthiah et al., 2002; Kasim et al., 2002), possibly because of lower length range encountered due to higher fishing pressure and differences in the gears used for exploitation (Pillai et al., 1993). Using pooled data from both the coasts, Somvanshiet al. (2003) recorded asymptotic length as $69.0 \mathrm{~cm}$ from the Indian waters. Higher values of growth co-efficient (1.0-1.6), has been observed by most authors (Kasim et al., 2002; Somvanshi et al. 2003; Ghosh et al., 2009), except Devaraj (1981). Length attained each year for five years were lower to those estimated by Rao (1978), Devaraj (1981), Naik et al. (1998) and Ghosh et al. (2009). Differences in environmental parameters and food availability, predation and exploitation, the type of fishing gears used and the methodology used in the estimation are the reasons attributed for variation in growth parameters. Longevity from the east coast in the present study is much higher than that reported from the west coast (Kasim et al., 2002; Ghosh et al., 2009). Length at first capture $(20.28 \mathrm{~cm})$ is similar to that reported $(21.05 \mathrm{~cm})$ from Veraval (Ghosh et al., 2009). It is much lower than length at first maturity indicating that majority of them were caught before they could mature and spawn at least once in their life. This indicated stress on spawning stock with consequential impacts on recruitment and could be addressed by increasing their size and age at exploitation.

Natural mortality and exploitation ratio in the present study is much lower when compared to 1.41 and 0.77 reported by Devaraj (1981) and 1.79 and 0.62 reported by Ghosh et al. (2009). Natural mortality coefficient of a fish is directly related to the growth coefficient $(K)$ and inversely related to the asymptotic length $\left(\mathrm{L}_{\infty}\right)$ and life span (Beverton and Holt, 1956). S. guttatus with lower growth coefficient of 0.23 per year and higher asymptotic length of $71.98 \mathrm{~cm}$ and lifespan of 13 years was found to have relatively lower natural mortality coefficient of 0.54 per year. $\mathrm{M} / \mathrm{K}$ ratio of 2.35 was within the normal range of $1-2.5$, as suggested by Beverton and Holt (1959). Z/K ratio of 1.0 is considered as growth dominated and if it is more than 2 , then it is mortality dominated. In the present study, it was higher than 4 , indicating that fishery of $S$. guttatus is highly mortality dominated (Pauly and Soriano, 1986).

With $E(0.48)$ very close to $E_{\max }(0.53)$ and annual average yield $(2,614 t)$, again very close to MSY $(2,747 t)$, further increase in yield is only marginally possible by increasing the present fishing intensity. By increasing the fishing effort by $20 \%$, a trivial $0.82 \%$ increase in yield is possible. Therefore, a more realistic management measure would be to pursue the present fishing effort without further increase. Moreover in a multispecies multigear fishery, as exists presently, changes in effort will have to take into consideration other target species as well. Seerfishes 
being highly migratory; multiple fisheries occur at different locii on the overall migratory routes and stock abundance depends on the condition prevailing elsewhere also. Thus, information gained from stock assessment will have its own limitations but will provide valid evidence necessary for management guidelines and can be taken as an indicator of the present status of the fishery off Andhra Pradesh. A seasonal ban on usage of small meshed gill nets is an option to reduce overfishing. Harvesting by highly selective gear viz., large meshed drift gill nets and hooks and lines will conserve the juveniles of seerfish.

\section{Acknowledgements}

The authors express their gratitude to Director, CMFRI for the constant support and encouragement during the study period. Financial support from Indian Council of Agricultural research is also highly appreciated.

\section{References}

Bal, D. V. and K. V. Rao. 1990. Marine fisheries of India. First Revised Edition. Tata McGraw-Hill Publishing Company Limited, New Delhi, 472 pp.

Beverton, R. J. H. and S. J. Holt. 1956. A review of method for estimating mortality rates in exploited fish population, with special reference to source of bias in catch sampling. Rapp. P. V. Reun. CIEM, 140: 67-83.

Beverton, R. J. H. and S. J. Holt. 1959. A review of the lifespans and mortality rates of fish in nature and their relation to growth and other physiological characteristics. In: Wolsenholmy, G. E. W. and M. O'Connor (Eds.), Ciba Foundation Colloquia on ageing, 5: 142-180

Devaraj, M. 1977. The biology and fishery for seerfishes of India.Ph.D. thesis, Madurai Kamaraj University, 337pp.

Devaraj, M. 1981. Age and growth of three species of seerfishes Scomberomorus commerson, S. guttatus and S. lineolatus. Indian J. Fish., 28: 104-127.

Devaraj, M. 1987. Maturity, spawning and fecundity of the spotted seer, Scomberomorus guttatus, in the Gulf of Mannar and Palk Bay. Indian J. Fish., 34(1): 48-77.

Gayanilo, F. C. Jr., P. Sparre and D. Pauly. 1996. The FAO-ICLARM Stock Assessment Tools (FiSAT) User's Guide. FAO computerized information series (Fisheries). No. 8. Rome, FAO, $126 \mathrm{pp}$.

Ghosh, S., N. G. K. Pillai and H. K. Dhokia. 2009. Fishery, population dynamics and stock assessment of the spotted seer in gill net fishery at Veraval. Indian J. Fish., 56(3): 157-161.

Gulland, J. A. 1979. Report of the FAO/UNDP workshop on the fishery resources of the Western Indian Ocean-South Equator. FAO, Rome, 10FC/DEV/79/ 45: 1-37.

Kasim, H. M. and K. M. S. A. Hamsa.1989. On the fishery and population dynamics of seerfish Scomberomorus commerson (Lacepede) off Tuticorin (Gulf of Mannar). CMFRI Bull. 44 (1): 46-53.

Kasim, H. M., C. Muthiah, N. G. K. Pillai, T. M.Yohannan, B. Manojkumar, K.P. Said Koya, T. S. Balasubramaniam, U. S. Bhatt, M. N. K. Elayathu, C. Manimaran and H. K. Dhokia. 2002. Stock assessment of seerfishes in the Indian seas. In: Pillai, N. G. K., N. G. Menon, P. P. Pillai and U. Ganga. (Eds.), Management of Scombroid Fisheries, Central Marine Fisheries Research Institute, Cochin, p. 108-124.
Kasim, H. M. and E. M. Abdussamad. 2003. Stock assessment of Seerfishes along the east coast of India. In: Somvanshi, V. S., S. Varghese and A. K. Bhargava (Eds.), Proc. Tuna Meet-2003,p. 86-96.

King, M. 1995. Fisheries biology, assessment and management, Oxford University Press, Oxford, UK, $342 \mathrm{pp}$.

Le Cren, E. D., 1951. The length weight relationship and seasonal cycle in gonad weight and condition in the perch (Perca fluviatilis). J. Anim. Ecol., 20: 201-219.

Maheswarudu, G.,G. S. Rao, P. Rohit, P.Laxmilatha, S. Ghosh and M. Muktha. 2013. Marine fisheries of Andhra Pradesh: a decadal analysis. Indian J. Fish., 60 (3): 27-33.

Muthiah, C., H. M. Kasim, N. G. K. Pillai, T. M.Yohannan, B. Manojkumar, K. P. Said Koya, U. S. Bhatt, T. S. Balasubramaniam, M. N. K.Elayathu, C. Manimaran, H. K. Dhokia and M. V. Somaraju. 2002. Status of exploitation of seerfishes in the Indian seas. In: Pillai, N. G. K., N. G. Menon, P. P. Pillai and U. Ganga. (Eds.) Management of Scombroid Fisheries, Central Marine Fisheries Research Institute, Cochin, p. 33-48.

Muthiah, C. N. G. K. Pillai, U. Ganga and M. Srinath. 2005. Stock assessment of Seerfishes along the west coast of India - A review. In: Somvanshi, V. S., S. Varghese and A. K. Bhargava (Eds.), Proc. Tuna Meet-2003, 97-111.

Naik, S. K., A. Tiburtius and S. R. Bhalkar. 1998. Biology of the seerfish landed by exploratory trawlers. Indian J. Fish., 45(1): 35-41.

Pauly, D. 1979. Theory and management of tropical multi-species stocks. A review with emphasis on the southeast Asian demersal fisheries. ICLARM Studies and Reviews 1, $35 \mathrm{pp}$.

Pauly, D. 1980. On the interrelationships between natural mortality, growth parameters and mean environmental temperature in 175 fish stocks. L. Cons. Ciem., 39 (2) 175-192.

Pauly, D. 1983a. Some simple methods for the assessment of tropical fish stocks. FAO Fisheries Technical Paper, No. 243, 52 pp.

Pauly, D. 1983b. Length converted catch curves. A powerful tool for fisheries research in tropics (Part-1). ICLARM Fishbyte, 1 (2): 9-13.

Pauly, D. 1984. Length converted catch curves. A powerful tool for fisheries research in tropics (Part-II). ICLARM Fishbyte, 2 (1): 13-14.

Pauly, D. and J. L. Munro. 1984. Once more, on the composition of growth in fish and invertebrates. Fishbyte, 2 (1): 21

Pauly, D. and M. L. Soriano, 1986. Some practical extensions to Beverton and Holt's Relative Yield per Recruit model. In: Maclean, J. L., L. B. Dizon and L. V. Hosillo. (Eds.), the First Asian Fisheries Forum, Asian Fisheries Society, Manila, p. 491-496.

Pillai, P. P., N. G. K. Pillai, T. V. Sathianandan and M. N. K. Elayathu. 1993. Fishery biology and stock assessment of Scomberomorus commerson (Lacepede) from the south west coast of India. Expert consultation on Indian Ocean tunas. 5th Session, Mahe, Seychelles, 4-8 October 1993. TVVS/93/2/2, 21 pp.

Randall, J. E. 1995. Coastal Fishes of Oman.University of Hawaii Press, Honolulu, Hawaii, 439 pp.

Rao, K. S. 1978. Size composition of catch and growth of Scomberomorus guttatus (BI. \&Schn) off Waltair. Summer School on Fishery Biology, College of Fisheries, Mangalore, p. 15-16.

Snedecor, G. W. and W. C. Cochran. 1967. Statistical Methods, Oxford and IBH Publishing Co., Calcutta, India, 593 pp.

Somvanshi, V. S., S. Varghese and N. G. K. Pillai. 2003. National Report on Tuna Fisheries, Research and Development in India, IOTC-SC-03-Inf. 6, p. 1-8.

Sparre, P. 1987. Computer programming for fish stock assessment. Length based fish stock assessment (LFSA) for Apple computers. FAO Fisheries Technical Paper, 101 (Suppl 2), $217 \mathrm{pp}$.

Sparre, P. and S. C. Venema. 1998. Introduction to tropical fish stock assessment, Part 1-manual. FAO Fisheries technical paper 306-1, Rev. 2.

Srinath, M., S. Kuriakose and K. G. Mini. 2005. Methodology for estimation of marine fish landings in India. CMFRI Special publication 86, 57 pp. 